\title{
Māori Writing: Speaking with Two Mouths
}

\author{
TINA MAKERETI
}

\begin{abstract}
Drawing on her own experiences as a novelist and anthologist, Tina Makereti explores the situation of the Māori writer as someone "speaking with two mouths," addressing and drawing from both Māori and Pākehā literary traditions and ways of expressing creativity. Considering some examples from her own fiction and the work of other notable writers such as Patricia Grace, Makereti argues for a richer, more expansive conception of Māori and New Zealand literary history, one drawing on, and acknowledging, Māori ways of imagining literature.
\end{abstract}

In the beginning was Te Kore, the Void or Chaos before anything existed (though perhaps we cannot say it was the beginning because it was the nothing and the not-nothing, the formless state of potential before anything began). Somehow, out of the many different and esoteric states of Te Kore, Te Pō emerged and manifested eons of long nights. Finally, whether born between Earth and Sky, Ranginui and Papatuanuku, or pre-existing them, Te Ao Mārama came into being and light came upon the world. The children of the Earth and Sky populated the world then, beginning with the atua or gods, and reaching down through the ages to us today.

All Māori creation stories follow this whakapapa (genealogy) one way or another-our arrival out of chaos and the many long dark nights of creation into the light. Think of it almost like the Big Bang and the Western scientific version of creation, for there are many parallels there. This is both creation story and karakia (prayer), whakapapa and invocation. You will hear this invocation over and over in many different forms almost anywhere you find Māori people gathered. It is the way we connect ourselves to the world and to each other.

Whakapapa means genealogy but also in Māori terms all forms of connection and relationship can be understood as whakapapa: it underpins all Māori knowledge systems. You might say our theoretical understanding of the universe is based in whakapapa. Whether we begin with the first genealogy at the inception of the universe or whakapapa that is closer to our present time, in any situation we first and foremost recognise where we come from and how we are related. This is what the pōwhiri ritual at the beginning of hui and tangi is about, among other things.

Te Kore may be known in Western terms as the Void or the Chaos, but it is also known to us as the place of pure potentiality. From this 'Nothingness' everything sprang. It is the place of nothing and not-nothing, the place of pure paradox. This, for me, is where creativity comes from, and so to whakapapa or link myself back to there is the most powerful thing I can do as a creative person. I try to remember that every time we create we are engaging the same spark of chaos and paradox, and recognising our connection to everything else.

In 2013 I graduated with a $\mathrm{PhD}$ in Creative Writing from Victoria University, and I attended two graduation ceremonies. For one I went into the city centre and celebrated with the thousands of others who were being capped that week. We were ushered on stage, given a warm greeting and our paper certificates, photographed, and ushered off again. Since I was receiving a doctorate, I had the honour of joining the ranks of the staff on stage, and for the first time in the many different graduations I had attended, I had a real sense of joining the academy. 
For the other ceremony, I joined a smaller but no less significant group at the gates of Te Herenga Waka Marae, and was welcomed with a powwhiri. We then entered the whare and were honoured with speeches, songs, and additional certificates. I had been to Māori graduations before, so all of this was familiar to me, but one thing that happened was unexpected. Each graduand was gifted with a taonga: pounamu or jade, our most precious stone. Because I had completed my doctoral study, I received an additional gift, this bone carving pendant:

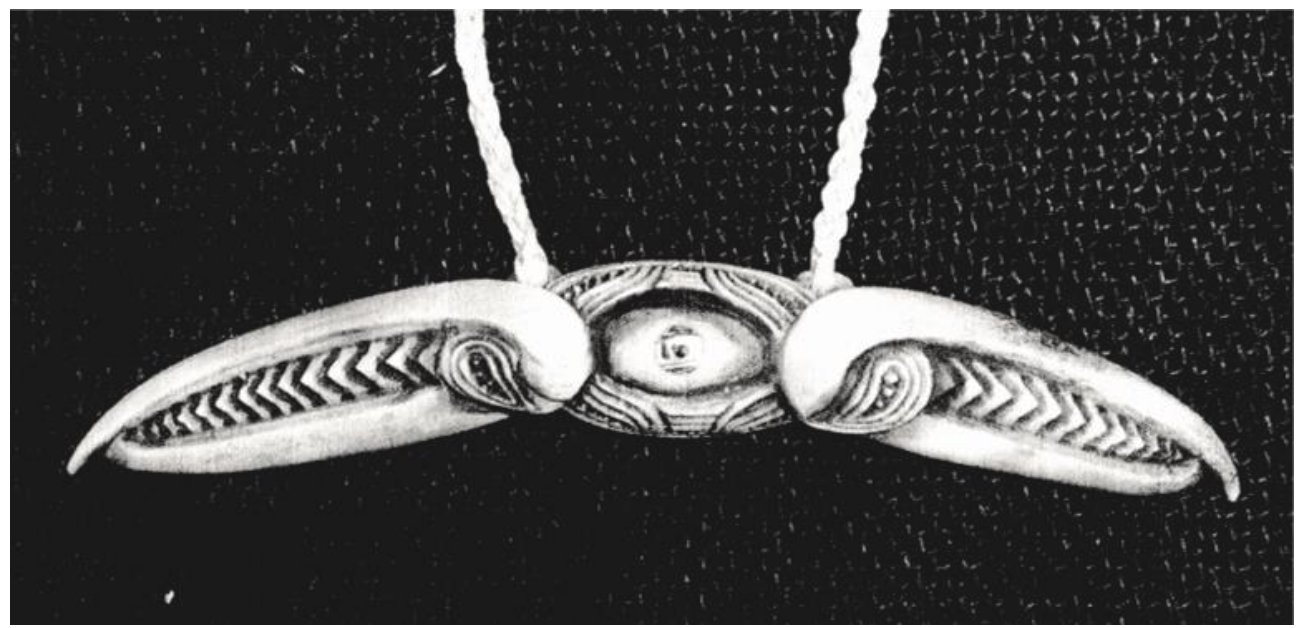

It's very beautiful, but also it held immediate and profound meaning for me as a writer. I'm not sure what was intended by the artist, but I can explain how I read this taonga. This is a manaia form, meaning a profile of the human head. The manaia can be very stylised, and the level of elongation that occurs in the mouth caused some early (non-Māori) theorists to suggest that the manaia is a bird form. My understanding is that it is not bird, though it might be spirit in many cases, going between the earthly and spirit realms. In this way the manaia is a figure of transformation and communication. 


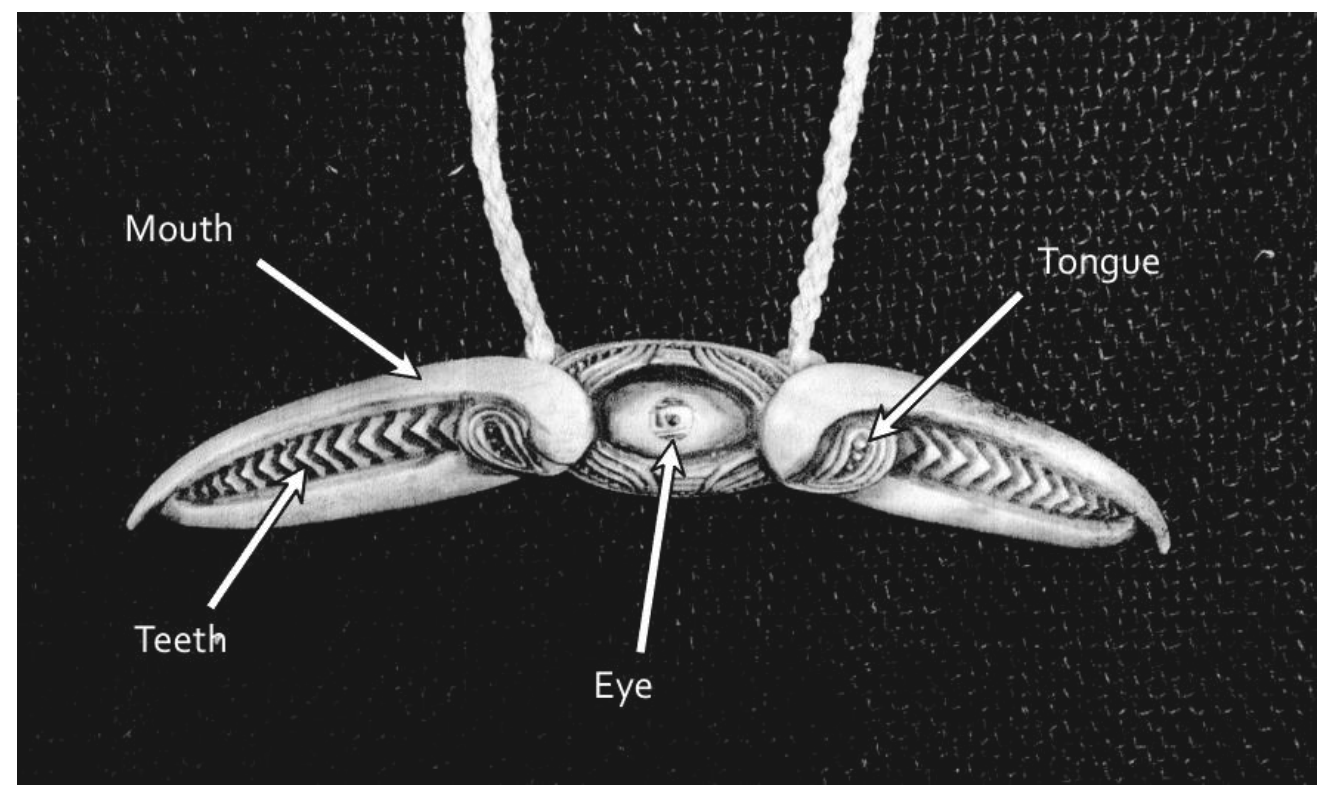

My taonga has a single eye and two mouths. The two mouths face in separate directions. On first seeing it I knew that this taonga represented the task of the writer, particularly the Māori writer: to speak with two mouths at once; to communicate between two sometimes opposing forces; to exist at the centre of the paradox. In particular, this taonga spoke to me as a mixed Māori-Pākehā individual telling the particular stories I tell, and as a Māori person writing in English. There is a duality in the fact of this act for Māori; writing in English is already an act of translation. But there is also added complexity in the modernity of the Indigenous writer. We are not performing simple translations into English of traditional ways of being or of pristine cultures. If we try to describe our cultures that way we end up solidifying something that was never solid. Our cultures, like any cultures, are in constant flux, so from the very first contact between Māori tribes and European settlers, our cultures transformed. What this means is that what we now think of as traditional is quite often already post-contact or postcolonisation. So my writing practice is always concerned with duality, contradiction, cultural fluidity and paradox. This taonga with its one eye and two mouths facing in opposite directions symbolises that for me. The two mouths speak:

Of the dead and the living

Of the earthly and the spiritual

Of past and future, and how those two things are interlinked: we can look in both directions at once

Of new things and ancient things

Of Māori and Pākehā, or, of Indigenous and Settler peoples

Of English and te reo Māori

Of communication styles that sometimes work in opposite ways

Of contradictory tikanga or cultural ways of doing things

Of male and female genders, the eye at the centre suggesting a continuum between one direction and another

Of those with power and those without

Of violence and peace. 
What this taonga represents in totality is the necessity to speak in both directions at once in all the work we do as Māori writers. We always have at minimum two audiences, even if we're simply talking at the very obvious level of Māori and Pākehā New Zealanders. We're constantly working with many conflicting dynamics, even if we're simply starting with the act of writing about Māori concepts with English words. We are in the constant act of bilingualism and biculturalism. At a deeper level, our position at the centre of such long-standing contradictory forces gives us immense power, if we can learn how to harness it. Histories, narratives and lecture plans that start from European assumptions will reproduce stories that centre European perspectives, and Māori writers and writing will end up at the margins, elsewhere to the main story. For example, the Māori Renaissance of the 1970s comes after the cultural nationalism of the 1930s; the short stories and novels of Witi Ihimaera are marginal to the main post-war story of the hunt for the "Great New Zealand Novel." But nothing could be further from how I see our work: we are in the centre of the fire, in the belly of the beast, and that's a place of immense creative energy. That is, in fact, Te Kore, the chaos, the origin place of the universe and all creativity, which brings us back to our creation story and our whakapapa.

\section{"The orthodox syllabus, its division into periods, its tag-names of certain kinds of writing in certain periods - that map is a construction." Raymond Williams ${ }^{1}$}

Even though the section above describes my understanding of what Māori writing is as a Māori writer, the way academia has taught our writing has been somewhat different, and the teaching of our literatures remains widely misunderstood, if given any attention at all. I don't want to undermine the interest and respect that has been evident from non-Māori who study Māori literature, because we need that interest to continue. However, historical and contemporary non-Māori approaches seem to be fundamentally different from the way we as Māori might understand what Māori literature is and how it should be taught. And the significance of Raymond William's work, particularly on the "selective tradition," is immediately recognisable.

The teaching of Māori literature in English departments in New Zealand Universities tends to look something like this:

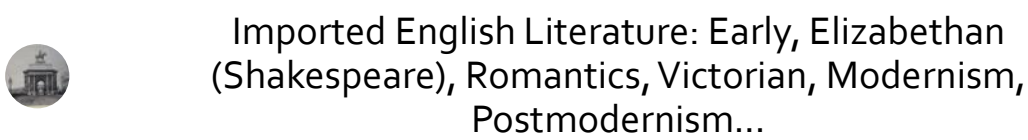

Imported English Literature: Early, Elizabethan Postmodernism...

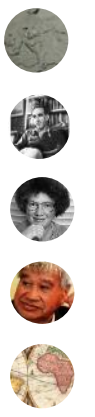

$19^{\text {th }} /$ Early $20^{\text {th }} \mathrm{C}$ NZ literature?

NZ 1930 Cultural Nationalists: Glover, Curnow, Fairburn, Brasch

1950 Neo-Romantics: Baxter, Campbell, Frame, Hyde

1970s: Wedde, Manhire; Mãori Writing:Tuwhare, Ihimaera, Grace

1990 onwards: Contemporary, postcolonial, global? 
A version of this schema is likely to be the kind of thing we use, though typically there are variations according to the perspective of the individual lecturer. The principle is that written literature arrived in the late eighteenth century with European settlers, that New Zealand literature emerged sometime in the early twentieth century (maybe late nineteenth century if you're particularly progressive) and that Māori literature arrived sometime in the 1960s (1950s or even 1930s if you're particularly progressive), with Hone Tuwhare's No Ordinary Sun (1964) and Witi Ihimaera's Роипати Роипати (1972) signalling the "beginning" of written Māori literature in English. This approach assumes that Māori were not creating substantial literature before this point. There has been important recent work challenging this way of imagining the literatures produced in these islands, and Arini Loader and Alice Te Punga Somerville have published powerful scholarship in A History of New Zealand Literature (2016) showing how much more rich, multifaceted, complex and long-standing Māori writing has been, and how many more places you can find it in the records of the past if you know where to look. But this scholarship needs a wider base of readers, teachers and respondents to be used at its full worth. The near absence of the teaching of Māori literature as a distinct subject in New Zealand universities makes this almost impossible. Māori literature is invariably placed as a subsection of New Zealand literature, which is still a regional subsection of English literature, and a late-arriving one at that.

My understanding of Māori literature in English, and how it should be taught so that scholars understand where it comes from and what it is saying, looks something a little like this:

\section{A Whakapapa of Māori Literature:}

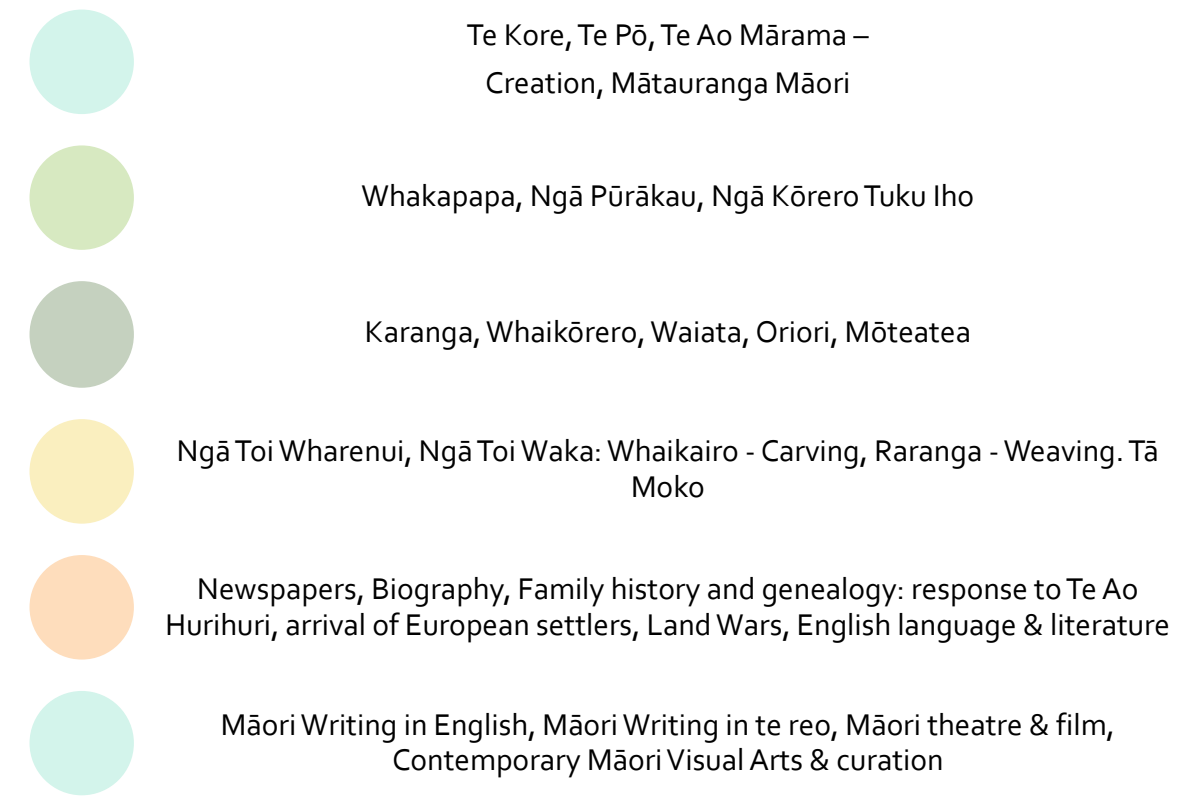

Or, perhaps more accurately, this: 


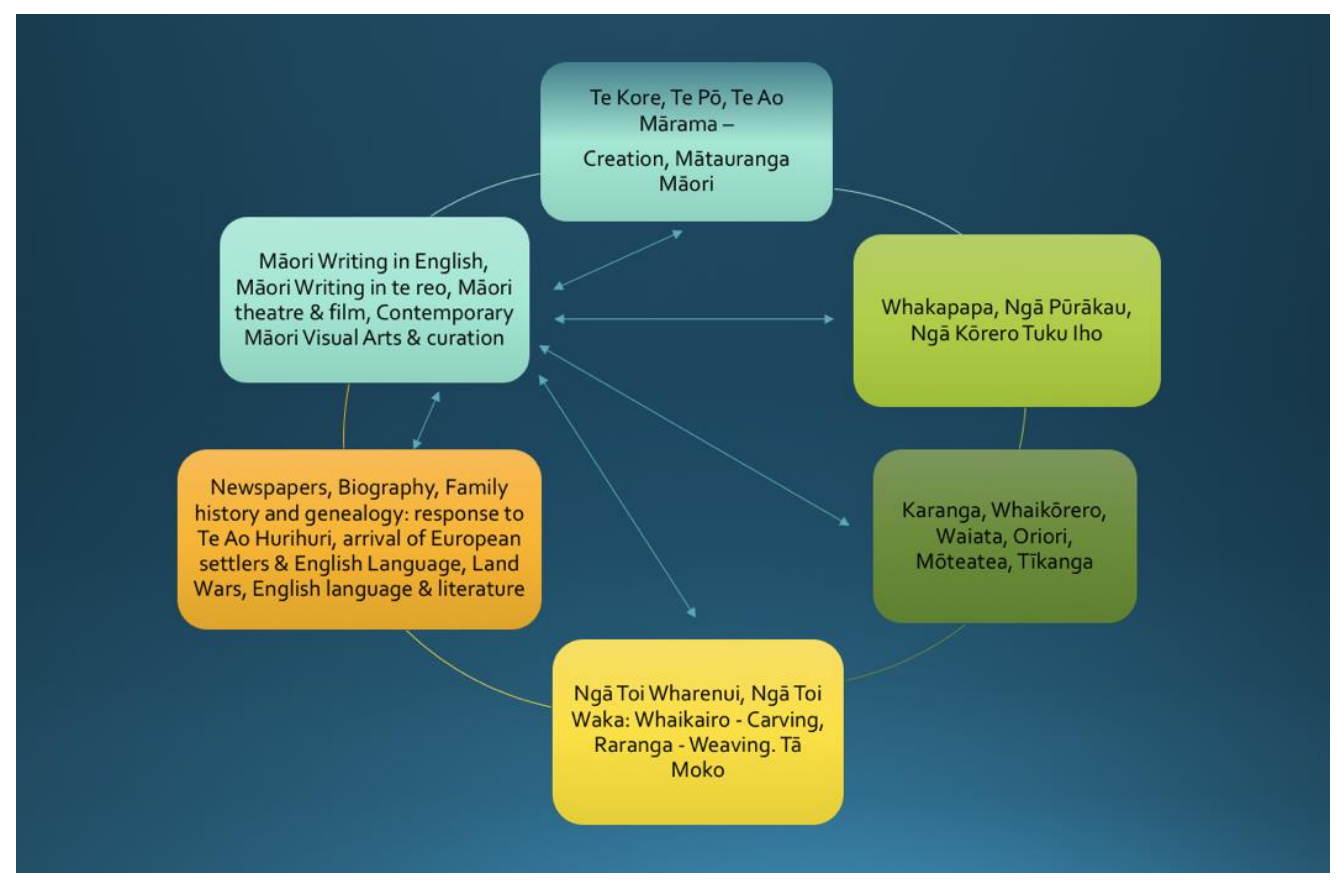

The final image attempts to delineate the exchange of ideas between past origins and present manifestations, particularly the sense that, while we might envisage whakapapa as something we are the product of (in a linear line), we must also recognise that our understanding of culture, stories, history and ancestors is transformed by the moment we find ourselves in. The whakapapa of Māori literature does not work in only one direction: culture is always in flux, and colonisation - and the ongoing process of colonisation - shapes, limits, distorts and shifts how we know and tell our own stories. We are constantly spiralling back to reconnect and reenact that whakapapa.

The whakapapa of Māori literature in English, as I envisage it, places writing in English and English literatures as a late but very important addition to a Māori literary heritage that was already extremely rich in literary forms and that had been long-established. And yes, this includes visual forms, in other words, 'written' literatures.

The difference between the two different systems is as profound as the difference between the Māori and English world views, to the extent that for me it is hard to imagine why you might choose to misunderstand Māori literature so fundamentally by viewing it only through the first one. What we need, in this bicultural nation, is at the very least the two systems existing side by side with one another, and what we urgently need is more Māori scholars of Māori literature to occupy this as-yet-unrealised field of study. The reasons why this hasn't happened yet are probably too complex to quantify here, so I will simply say that they are a product of colonisation and institutional bias, but that there are many complexities. Māori literature in English seems to occupy a space that puzzles both English literature departments and Māori studies departments, being essentially a hybrid of both.

I quite like occupying this inbetween space as my taonga that speaks with two mouths testifies, but it can be discomforting and uncomfortable, and things that don't fit are apparently easy to ignore and dismiss. 
Of course, there is a deeper history here of how English literature has always been set up to privilege only one kind of seeing, and what my first encounters with Raymond Williams offered me is a history that demonstrates how that selective tradition is built in, and how it leaves other traditions out. Hence it has been a great pleasure and privilege to encounter his work.

In my own work I have been lucky to encounter few negative responses, though it sometimes worries me that this is somehow due to a lack of comparative work or the ability to engage with Māori literature on its own terms. But one element of feedback about my last novel illustrated for me the difference in world views I attempt to describe here. The main Moriori ancestor character in Where the Rēkohu Bone Sings is not physically alive. I dislike calling him a spirit or a ghost because that is not what he is. I'm not sure he is even a kēhua, the Māori word for such beings. He is simply not alive, but he has lingered around his descendants because of the manner in which he was killed, in the invasion of Rēkohu (Chatham Islands), and eaten. Cannibalism was traditionally used in Māori warfare to desecrate and insult the dead, and steal their mana (personal, ancestral and sovereign power). If you aimed to demoralise and conquer an enemy, this was a strong tool for doing so. Moriori, the Indigenous people of the Chatham Islands, had outlawed the practice hundreds of years before Europeans, and then Māori, began to visit their islands. It makes complete sense that this manner of death, as the strongest possible act of desecration, would prevent a person from finding peace in the afterlife, particularly a person whose whole culture is based on non-violence.

The character I speak of is named Imi and he speaks to us directly in first person in the novel. I made everything about him up: his improvised, non-standard, negotiated English, the manner of his afterlife, the manner of his life before death, but Imi had arrived in my imagination very distinctly by waking me up at 4am for many nights, telling me his story. He is a character in a book, but sometimes, if we're lucky, our characters come to us that urgently. My job was to translate his story for the page.

Two things struck me about the response to Imi in reviews of the book. One, few critics knew what to make of him. Many readers told me they loved him, but many commentators didn't 'get' him. In other words, they were not convinced by him because he wasn't alive, or because of his manner of speaking (this last I accept as a valid criticism of the writing). Almost without exception, reviews described him as a useful or clever narrative device, using that exact phrase: narrative device. I guess everything in a book is a narrative device, but I wondered why so many critics had trouble reading or describing Imi as a character as real as any of the other characters. It hadn't occurred to me that readers (and I do mean the predominantly non-Māori or Moriori reviewers) would have difficulty digesting a character because he's not alive. After all, all characters are figments of our imagination, and for Māori and Moriori people, being dead doesn't necessarily make you less present.

The other thing was that few reviewers engaged with the manner of Imi's death in any depth. This had been so difficult for me to write, and so important to Imi as a character, and so important to the story. The one exception came from a non-Māori blogger, Morgan Davies, who wrote an eloquent and insightful analysis of the passage that describes Imi's cannibalisation, thus:

As the spirit becomes attuned to his new afterlife, his relationship to his body changes, and the perspective of the invaders slowly approaches knowability in his eyes. The crucial moment comes as he witnesses part of his body fed to an infant, and through 
this moment, leaves his body and moves perspective to hers. The description, unflinching in the detail of chewing and swallowing and digestion, is subsumed under the child's innocence, and the spirit becomes able through [the child] to perceive the other oppressors as people driven by their own fears and needs and loves. The sequence becomes, somehow, beautiful. ${ }^{2}$

To which I responded, with gratitude:

the whole book is about the humanity of the various participants. Imi is the voice of those who aren't usually given voice: the dead, the victims, history's "losers." The story is his, he owns it, he speaks it, and thus the story is somehow given back to him. Rather than using it to put down his enemy, this power gives him the ability to see his attackers in their humanity. And this might be the most important thing about Moriori culture, perhaps this is the heart of pacifism - the decision to see everyone as human and therefore "just like me" somehow. And to know that you don't have the right to take that away. ${ }^{3}$

It was only when Davies published his blog that I realised I had been waiting for anyone at all to engage with this aspect of the book, which was "for me ... the crux of the novel-I remember working on this passage, and thinking about how this was a crucial moment for the character Imi, for me as writer, and hopefully, for the reader." Academic analyses might go deeper than reviews, and it's not unusual for a writer's intentions to go unrecognised by readers, but I suspect the inability of reviewers to engage with Imi as a character and with the intricacies of his death and cannibalisation are, at least in part, due to an inability to read the work in its cultural context. None of this means that one must be Māori to understand the work (Davies isn't), but that one needs more than the tools of English literary studies' traditional critical methodologies to get the most from it. This is one small example of why we need a new way (or possibly an old way) to read Māori literature in English, and I will furnish you with one more-one that reminds me of Raymond Williams' own approach.

It surprises me how often I've referred to this example, and how often this example has been instructive-how it continues to surprise in both its simplicity and depth. Patricia Grace mentions this story often herself, and I suppose that's because it is still relevant - it continues to highlight how our seeing, like our tradition, is selective. So I'll quote Patricia herself:

When Potiki first came out there was quite a bit of criticism of it. One of the reasons was because of the use of Māori terms and passages in the book; the other was that some people thought I was trying to stir up racial unrest. The book was described as political. I suppose it was but I didn't realise it. The land issues and language issues were what Māori people lived with every day and still do. It was just everyday life to us, and the ordinary lives of ordinary people was what I wanted to write about, so I didn't expect the angry reaction from some quarters. ${ }^{4}$

As Māori writers, we are all speaking with two mouths, sometimes without being aware of it. Patricia was simply writing the everyday, ordinary stories of her community, which others read as radical and political. And of course they are, but more because of the assumptions that go hand in hand with accusing people of "trying to stir up racial unrest" simply by describing their lives. In the new fiction anthology Black Marks on the White Page, Witi Ihimaera and I dubbed this radical ordinariness. It's amazing what you discover when you look in a different direction, speak with a different voice, step into another's shoes. This is what all literature does, of course. The ordinary lives of ordinary people. But then, what is ordinary in one community cannot be assumed to be ordinary in another, and if we select only one version of things as our national 
literature, and if we select only one way to interpret our literatures, we're all at risk of missing the point. This is what I take Williams to mean when he writes that "culture is ordinary: that is the first fact." Ordinary here does not mean uninteresting or unremarkable. It is to do with community, and with collectively produced difference. "Every human society," Williams goes on, "has its own shape, its own purposes, its own meanings. Every human society expresses these, in institutions, and in arts and learning. The making of a society is the finding of common meanings and directions, and its growth is an active debate and amendment, under the pressures of experience, contact, and discovery, writing themselves into the land." "If we do not seek out Māori ways of "finding common meanings and directions," and if we overlook the connections Māori writers have made and continue to make in their own shapes, purposes, and meanings, all of us-students and readers, writers, Pākehā scholars as much as Māori-will miss the chance to see the "active debate and amendment" going on around us.

Many Pākehā readers of Potiki discovered that a world existed alongside their own that until then had been invisible to them, and many responded positively. So whether you are from Wales, or Plimmerton, New Zealand, or maybe from Japan, telling your own story in your own vernacular (in your own way of speaking) can be both ordinary and radical. This is another example of the two mouths with which us writers speak, two mouths that seem to face in opposite directions, but emanate from the same source.

\footnotetext{
${ }^{1}$ Raymond Williams, “The Future of English Literature.” In What I Came to Say (London: Hutchinson, 1989), 153.

${ }^{2}$ Morgan Davie, "Where the Rēkohu Bone Sings: A Few Thoughts." From the Morgue. 12 March, 2014. http://morgue.isprettyawesome.com/?p=6548

${ }^{3}$ Tina Makereti, “An Amazing Year, An Important Review.” Tina Makereti. 23 March, 2015. https://www.tinamakereti.com/k332rerorero/an-amazing-year-an-important-review

${ }^{4}$ Adam Dudding, "Patricia Grace: The Interview." Academy of New Zealand Literature / Te Whare Mātāhui o Aotearoa. Accessed May 2018. http://www.anzliterature.com/interview/patricia-grace-inconversation-with-adam-dudding

${ }^{5}$ Raymond Williams, "Culture is Ordinary." In Conviction, edited by Norman MacKenzie (London:

MacGibbon and Kee, 1958), 75.
} 